\title{
A holistic study for assertive communication of a business website with the client: plugins
}

\section{Un estudio holístico para la comunicación asertiva de un sitio web empresarial con el cliente: plugins}

HERNÁNDEZ-CRUZ, Luz María†*, DE LA CRUZ-EK, Oscar Ezequiel, CHAN-CAUICH, Víctor Manuel and ORTIZ-CUEVAS, Nancy Georgina

Universidad Autónoma de Campeche, Mexico.

ID $1^{\text {st }}$ Author: Luz María, Hernández-Cruz / ORC ID: 0000-0002-0469-5298, Researcher ID Thomson: H-3153-2018, CVU CONACYT ID: 662220

ID $1^{\text {st }}$ Coauthor: Oscar Ezequiel, De la Cruz-Ek / ORC ID: 0000-0003-0221-1269, CVU CONACYT ID: 1065298

ID $2^{\text {nd }}$ Coauthor: Victor Manuel, Chan-Cauich / ORC ID: 0000-0002- 3432-4877, Researcher ID Thomson: I-5555- 2018, CVU CONACYT ID: 904854

ID $3^{\text {rd }}$ Coauthor: Nancy Georgina, Ortiz-Cuevas / ORC ID: 0000-0003-4191-9630, CVU CONACYT ID: 964285

DOI: $10.35429 / J B A B .2020 .6 .4 .32 .40$

Received January 20, 2020; Accepted June 30, 2020

\begin{abstract}
Today, the image of a company depends substantially on its online presence, the existence of a business website has become a necessity. With this, it is essential to establish assertive communication with customers in order to win and care for their preference. The general objective of this research is to apply a holistic approach and methodology that allows the use of plugins to be applied in practice as a tool to add value to the design, functionality, use and communication of customers with business websites. This as part of the necessary skills or competencies in the learning of students in the area of computer science and technologies with an innovative approach, helping to encourage research in this context. The methodology is carried out from the holistic research process proposed by Hurtado (2006), showing the ten phases in detail in the proposed technological application. Concluding that the holistic approach is fully adaptable for research in the area of computer science.
\end{abstract}

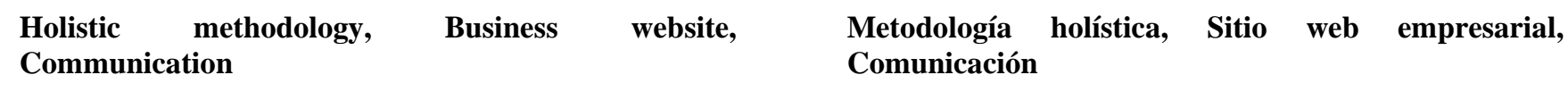

\begin{abstract}
Resumen
Hoy en día, la imagen de una empresa depende sustancialmente en su presencia online, la existencia de un sitio web empresarial se ha convertido en una necesidad. Con ello, es imprescindible establecer una comunicación asertiva con los clientes con la finalidad de ganar y cuidar la preferencia de los mismos. El objetivo general de la presente investigación es aplicar un enfoque y metodología holística que permita aplicar en la práctica el uso de plugins como herramienta para agregar valor al diseño, funcionalidad, uso y comunicación de los clientes con sitios web empresariales. Esto como parte de las habilidades o competencias necesarias en el aprendizaje de estudiantes en el área en ciencias de la computación y las tecnologías con un enfoque innovador contribuyendo a incentivar las investigaciones en este contexto. La metodología se lleva a cabo a partir del proceso de investigación holístico propuesto por Hurtado (2006), exhibiendo las diez fases detalladamente en la aplicación tecnológica propuesta. Concluyendo que el enfoque holístico es totalmente adaptable para investigaciones en el área en ciencias de la computación.
\end{abstract}

Citation: HERNÁNDEZ-CRUZ, Luz María, DE LA CRUZ-EK, Oscar Ezequiel, CHAN-CAUICH, Víctor Manuel and ORTIZ-CUEVAS, Nancy Georgina. A holistic study for assertive communication of a business website with the client: plugins. Journal-Business Administration-Marketing; Accounting. 2020. 4-6:32-40.

$\uparrow$ Researcher contributing first author. 


\section{Introduction}

The word holism comes from a Greek word (yólos) that means everything, totality, completely. Holistics considers each system as a whole in which its parts are integrated. The study of each of the parts of a whole cannot explain how the system works in a global way. A system is much more than the simple sum of the parts, that is why this study method considers the synergism of the parts as important and not the individuality of the parts.

Likewise, it is stated that science and technology must respond to real needs and be accessible and shared by everyone. The emergence of a knowledge society is the most important paradigm shift of the next half century. A holistic approach and methodology are imposed that allow the gradual construction of sustainable societies with a constant increase in the quality of life for all. (Aguiar, 2005)

The teaching-learning process as a sociocommunicative and practical action between the teacher, students, context (educational community) and training program, is carried out as a deep scenario and reality in continuous complexity, which needs to be investigated in its entirety: holistic-integrated approach, but descending to microanalysis, which enable the knowledge of didactic integration in the plurality of situations, scenarios, moments and technological impacts in which this rigorous knowledge provided by research makes sense. Faced with this need to discover holistic problems related to the complexity of the teaching action, the advance in close complementarity of micro socio-communicative problems experienced in the training actions is demanded to understand the didactic act and train students in the skills: communicative, artistic , digital, social, knowledge of the world, teamwork, time organization, leadership, etc., which show the proliferation of situations, object of investigation. (Medina Rivilla, De La Herrán Gascón, \& Dominguez Garrido, 2014)

In this sense, this research proposes an exploratory or formulative study to apply the holistic methodology in the implementation of technological tools that allow assertive communication on a business website.
Students of Educational Programs in Computer Science must be able to know and apply their own technological tools for the design of business websites. Learning as action in practice will allow the achievement of this objective.

The central hypothesis of this research is defined as "The holistic methodology can be adapted for the practical application of its own technological tools (plugins) for assertive communication on business websites".

The study generates added value with the use of holistic methodology as a new research option in the area of Computer Science and Technologies.

The main sections of the article are:

\section{Methodology}

The holistic research process proposed by Hurtado is like a spiral, where its cycle begins with the exploration phase in which the observation and identification of facts are of great relevance and significance (Hurtado de Barrera, 2006). Once identified, the description phase is presented, which consists of determining the characteristics or qualities of the events studied. The second phase is the comparison phase, where the event is studied to see if it manifests itself differently in other contexts. Joined to it is the analysis phase, in which the researcher enriches the study event in terms of criteria, giving him a greater openness in understanding it.

Then the explanation phase, or search for the processes or causes that generate the studied events, here the theories are born, which provide conceptual support that gives guidance to the researcher to be able to make certain predictions of the event, presenting the predictive phase; which consists of predicting the Hypothesis that requires verification, for which it is necessary to apply a research design or an action plan in which it is determined how the events will be controlled or modified. The designs are part of the proposal or projective phase, and the execution is considered an intervention where the researcher interacts with the context where the event takes place, expressing here the interactive phase. 
The analysis of the results of the intervention carried out allowed us to enter the confirmatory phase, which consisted in understanding whether the hypothesis put forward is correct; and if the researcher wishes and believes necessary to evaluate the results of the intervention, thus reaching the last phase: the evaluative (Carrasquero Medina, 2014). Figure 1 shows the Phases of the Holistic Research Cycle.

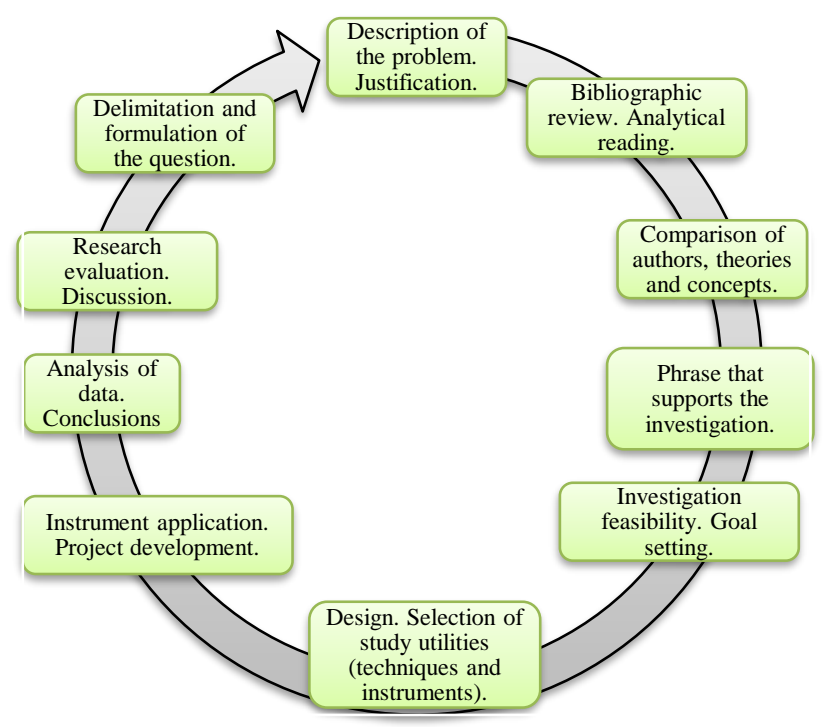

Figure 1 Phases of the holistic cycle of research Source: (Hurtado de Barrera, 2006)

\section{Phase I: Exploration or exploratory phase}

The first phase allows us to identify the facts, then the main concepts of plugins as a technological tool for assertive communication within business websites are described.:

- Web Management is more than information management, management is important for the user (who visits the website) and the developer (who creates the website), so that they have the necessary information.

- $\quad$ Plugins are applications or software that contain a group of functions or characteristics, which help improve WordPress (Jaime Tagle, 2020).

Trust is a strategic aspect of modern business management and in a wide variety of contexts, including marketing. Research has highlighted the importance of trust as an enabling instrument (James Ariel Sánchez Alzate, 2016).
- The online consumer is one who makes use of information technologies to purchase products through web platforms or online applications, in many cases, influenced by online communities, trust and web page design (James Paul Linero Bocanegra, 2020).

It has been shown that when a person embraces the Internet as a marketing channel, trust becomes a fundamental component. (James Ariel Sánchez Alzate, 2016)

\section{Phase II: Description or descriptive phase}

A WordPress plugin (plugin) is a program or a set of one or more functions written in the PHP scripting language, which adds a specific set of features or services to the WordPress site. You can seamlessly integrate a plugin with your site using the access points and methods provided by the application program interface (API) of the WordPress plugin (WordPress.org, n.d.).

To ensure a simple and transparent process in the use of plugin on a website, you must consult the directory of plugins.

Specifically the goal of the WordPress plugin directory provides a safe place for all WordPress users, from non-technical to developers, to download plugins that are consistent with the WordPress project goals and desired requirements (WordPress.org, sf).

Plugin technology is generally associated with the Internet, for example it is used to provide web browsers with new capabilities, such as to play multimedia files, view interactive 3D media, play sound and video files, perform calculations, etc. (Tony Millio, 2004).

The main specifications that a plugin must meet in order to be implemented on a business website are security standards, easy to implement and also be intuitive.

A flexible and secure plug-in architecture allows plug-ins to dynamically interconnect in highly flexible arrangements to allow handling of many types of file formats. The interconnection is self-administered through a system of supervised volunteers. (Tony Millio, 2004) 


\section{Phase III: Analysis or analytical phase}

Business websites are "the company" within the reach of users, who frequently require some kind of support or cannot find the information they need, problems that in the long term cause customers to seek other alternatives and end up choosing to leave the competition. As Peciña says: The platform, as the only way of access to the client, must be capable of solving the needs of the clients throughout the process and relationship model. (Peciña, 2017).

The tools that allow adding a communication channel of the website with the client. Among the plugins that offer these chat services are:

Genesys cloud. With its open APIs, and tremendous scalability and reliability, Genesys Cloud is the world's leading public cloud architecture platform that helps all businesses, regardless of size, deliver better customer and employee experiences.

Cliengo. Cliengo is an automatic chat program that offers visitors the possibility of leaving their contact details to be referred to a commercial representative. Cliengo's Online Chat allows customers to start a conversation with an agent from the same web page. If the agent is not available, Cliengo simulates a human conversation requesting telephone and email and sending this data, along with the conversation to the real agent.

Tawk.io. It is an automated chat program that provides unlimited number of agents, simultaneous conversations and history, as well as features such as agent evaluation and automatic messages.

Zendesk. It is one of the best solutions to improve the customer service of any business on a large scale, it offers a complete statistics system, and it also integrates an automatic chat (Zopim).

Track chat. Integrated chat in real time that allows the management of potential clients. You can connect guests to the right agents using skill-based routing. Integrated with CRM, the guest history is made available to agents.
- ChatBot. It is a web tool that allows us to develop chatbots that automatically and intelligently answer user questions.

WhatsApp Business. is a free downloadable application designed with small businesses and businesses in mind. WhatsApp can also help small and medium-sized businesses to provide technical support to their customers and send them important notifications. Create a company profile with useful information for your clients such as your address, company description, email address and website.

In this study it is proposed to obtain assertive communication by adding to the website:

- $\quad$ Live chat: It is the textual conversation that is usually generated when the client is visiting a web page, with this tool, online help is offered after a minimum time of stay on the site has elapsed (Bernal, 2019).

- Automatic chat: The system answers automatically (Bernal, 2019).

\section{Phase VI: Comparison or comparative phase}

In this phase, we will address the comparison of authors of theories, concepts and characteristics of a business website and the importance of communication channels with customers.

A business website is used to manage the presence of the company on the Internet to publicize its products and services. Hence, its importance when interacting with customers, as Peciña says "The platform, as the only way to access the customer, must be able to meet customer needs throughout the process and relationship model" (James Paul Linero Bocanegra, 2020).

A new user should have no difficulty instantly understanding what the company is offering for him. The variables that favor communicative efficiency between the company and the users of a web page are, fundamentally, usability, interactivity and content ( $¡$ Kaplanidou and Vogt, 2006; Ha \& Love, 2005; Kline et al., 2004; Morrison et al.). 
Usability is the measure of the quality of the experience that a user has when interacting with a product or system. This is measured through the study of the relationship that occurs between the tools and those who use them, to determine the efficiency in the use of the different elements offered on the screens and the effectiveness in fulfilling the tasks that can be carried out. out through them.

Interactivity can be defined in many senses. For example, the pioneering work of Blattberg and Deighton (1991) defines interactivity as the ease with which people and organizations can communicate directly with each other, regardless of the distance or time that separates them.

Content. The content of a website can be defined as the combination of functional information text and motivational visuals that encourage the user to plan a trip to the destination. Content is important for Internet communications because the Internet was initially developed to exchange information (Evans and King 1999; Nielsen 1995).

Comparing these three characteristics with the use of business websites, clients in most cases are not able to discover all the components or parts of the page, which is why it is very useful to provide tools that allow us to communicate with them to solve your doubts or solve your problems. Navigating the business website must be efficient and simple, for this, there is nothing better than a good structure and including communication tools and customer service.

Plugins have the great ability to adapt to the project in which they will be implemented, they are applications or software that contain a group of functions or characteristics, which help improve the performance of the website. Among the plugins there are a great variety of options, we can find tools that help to connect directly with users using live chat or automatic chat, tools that are not visible to users but help administrators to know their Market by Through CRM (Customer Relationship Management) or handling of Cookies, plugins for the management of user accounts, design, structure and architecture of the website and even the creation of an online store to mention some of the most used.

\section{Phase V: Explanatory or explanatory phase}

Customers are the most important part of a business website, they visit the site and it is for whom it is made, that is why it is important that the client or potential client feel safe and comfortable in it, they must feel that the company is interested and that he has what he needs. In the same way, the company needs to know the interests of the client, what he wants and what he is looking for. The business website allows you to do this in two ways, the first is directly, with live chats where it is necessary that there be one or more employees responsible for attending and answering customers, and the second, where it is automatically It gives the user what he needs, at this point, there are several alternatives to add the functionality, the best known are cookies, CRM, and automatic chats or chatbots.

Plugins are an important part of software development today; a plugin can be a tool that saves programmers endless hours of work to solve a problem that someone else has already solved. These applications require a flexible architecture to adapt to the different types of projects in which their functionalities and characteristics will be implemented and granted.

\section{Phase VI: Predictive phase}

The most effective way to reduce the possible errors of users or that they do not find the information they need is by developing the website with a good structure, dividing the information into different blocks, in the same way making the site attractive in a minimalist way and with the most important information or functionalities at sight; also, consider the implementation of communication tools such as automatic chats and the inclusion of social networks. The elementary functionalities to consider are:

Forms. With these we can offer the specific information that the user needs, in addition to helping us to know the information that is most relevant to users. The design of contact forms is really easy and you can also use plugins to add this functionality. Contact Form 7 is a popular and free plugin, which generates a basic and reliable contact form. This plugin includes documentation, frequently asked questions, a support forum, and a website with information.

HERNÁNDEZ-CRUZ, Luz María, DE LA CRUZ-EK, Oscar Ezequiel, CHAN-CAUICH, Víctor Manuel and ORTIZ-CUEVAS, Nancy Georgina. A holistic study for assertive communication of a business website with the client: plugins. Journal-Business AdministrationMarketing; Accounting. 2020 
Integration of communication channels via WhatsApp or Messenger since they are the most used communication applications. Millions of users have WhatsApp installed on their smartphones. Sirena is a plugin that allows you to add integration functionality with WhatsApp. As if that were not enough, its interface is as simple to use as those that the user is used to: not only in WhatsApp and WhatsApp Web, but also in alternatives such as WhatsApp Click to Chat or WhatsApp Help Chat Button.

Including interaction with social networks, you can also attract customers on a business website. A Plugin for Facebook Messenger is the FB Customer Chat Plugin with Autowelcome Responses, which fits with any type of company of any line of business. Place a Facebook Messenger chat on the pages of your choice within your website.

A section of frequently asked questions and opinions of the users. The Everest FAQ Manager plugin is a perfect tool to optimize communication with customers. Everest FAQ Manager has 24 layout templates available to create a FAQ section.

Within the vast set of plugins that are available, we refer only to those that can create an assertive communication channel with the customer, a channel through which he can have information about the site and the site obtain user data.

\section{Phase VII: Proposal or project phase}

Businesses look at their website as a means of attracting new customers and thus increasing their productivity and profits. There will always be new customers who, for the most part, seek to find information or carry out an operation through the site, hoping it is easy, simple and fast. On some occasions, this does not happen, that is why it is necessary within the site, that the information is legible and the navigation within intuitive, in addition to tools for interaction with the company staff that can provide immediate support such as implementing the frequently asked questions sections and the integration of automatic chats and real-time chats through plugins.
The use of plugins that integrate chats to the business website, whether they are autonomous or in real time, is considered the most effective since it allows us to obtain feedback from employees ("the company") directly and effectively. It is also important to highlight that in the market there may be proposals to implement the use of plugins, complying in the first instance with the standards for their correct execution. Open source standards such as TAR and MySQL formats, as well as privacy, security and quality standards:

\section{- $\quad$ ISO 2500n: quality management.}

ISO 2501n: quality model: composed among others by reliability, security, maintainability and usability.

\section{Phase VIII: Interactive phase}

One of the most important phases of the holistic process cycle in the implementation of tools for assertive communication is interactive. In this study the interactivity is between the business website and the customers. To do this, the plugins proposed to add this capability to the business website are analyzed. Figure 2 shows the Communication Plugins for a business website.

\begin{tabular}{|c|c|c|c|}
\hline Plugin & Rating & Cost & Technology \\
\hline Tidio & 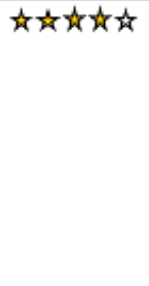 & $\begin{array}{l}\text { Basic: Free } \\
\text { Pro: \$15 } \\
\text { USD mouth }\end{array}$ & 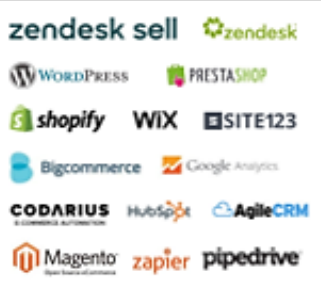 \\
\hline JiroChat & 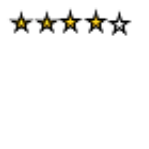 & $\begin{array}{l}\text { Basic: Free } \\
\text { Pro: S15 USD } \\
\text { mouth }\end{array}$ & 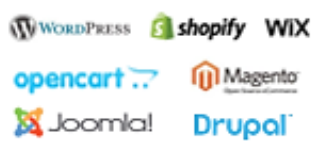 \\
\hline Tawk.to & 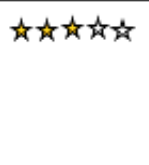 & $\begin{array}{l}\text { Basic: Free } \\
\text { Pro: \$15 USD } \\
\text { mouth }\end{array}$ & 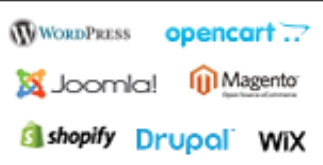 \\
\hline Smartsugp & 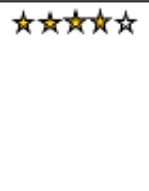 & $\begin{array}{l}\text { Basic: Free } \\
\text { Standard: \$10 } \\
\text { USD/ mouth } \\
\text { Pro: \$23.75 USD/ } \\
\text { mouth }\end{array}$ & 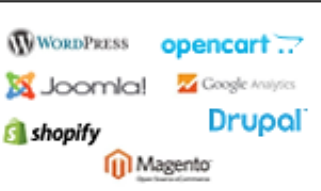 \\
\hline Pure Chat & 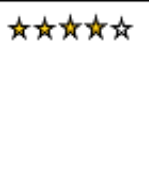 & $\begin{array}{l}\text { Basic: Free } \\
\text { Intermedium: } \$ 49 \\
\text { USD mouth } \\
\text { Pro: \$99 USD } \\
\text { mouth }\end{array}$ & $\begin{array}{l}\text { tumblr. Gs shopify } \\
\text { WWoroPress } \odot \text { sdcart } \\
\text { Weebly Hubspóst Wix }\end{array}$ \\
\hline
\end{tabular}

Figure 2 Plugins for communication within a website Source: Own elaboration

HERNÁNDEZ-CRUZ, Luz María, DE LA CRUZ-EK, Oscar Ezequiel, CHAN-CAUICH, Víctor Manuel and ORTIZ-CUEVAS, Nancy Georgina. A holistic study for assertive communication of a business website with the client: plugins. Journal-Business AdministrationMarketing; Accounting. 2020 
Tidio. It offers very good functions at low prices, one of them is to be able to see the message that the user writes before sending it and thus be able to offer faster responses, recover abandoned carts to increase income and offers statistics on users in real time and integration with external tools like Zendesk.

JivoChat. It allows up to 5 agents (operators) in its free plan, which makes it very useful for teams. On the other hand, it offers support entirely in Spanish, something that can save you a lot of problems (and time) in its use. This plugin allows us to connect different types of platform to connect with our clients, in addition to helping the connection through calls that we can make at the time and date that the client prefers. and it helps us to be able to carry out an Administration based on the relationship with clients (CRM). and many more extra features like even qualifying the service offered.

Tawk.to. They provide an unlimited number of agents, simultaneous conversations and history, as well as features such as agent evaluation and automatic messages that are often paid features in other solutions. But to remove your brand from the chat has a very high cost, so when you pay for it you practically end up charging you for most of the supposedly free features. Another advantage is that it helps you find agents to serve your clients if you need it, at an affordable price.

Smartsupp. Their free package has excellent technical features (such as an unlimited number of agents). It allows you to record what the visitor does on your website to understand, among other things, "why did I leave your website" and the possibility of using Google Analytics. Its disadvantages are the support and the fact that its brand cannot be removed in any plan.
Pure Chat. Its free version sets very few limits and its paid plans offer great benefits, mainly due to the agents and the design customization that they provide for your chat, compared to other plugins. It also offers integrations with apps like HubSpot and with its detailed statistics system, which allows you to mainly evaluate the performance of your attendees.

\section{Phase XI: Confirmatory phase}

The communication channels created through the plugins can serve as a medium or channel in the relationship between the interested parties, giving the client a feeling of security and interest in the business website.

The business website, on the other hand, receives a better analysis on its clients to know and recognize their weak points (vulnerabilities) and the opportunities for redesign and maintenance.

The company will be able to implement management strategies by knowing the interests and preferences of customers by having direct interaction with them.

All plugins have among their characteristics to grant functions through a payment with which they increase the quality of the service, these additional functionalities are more than paid in utility by considerably improving the experience of customers when browsing the business website.

Each company will be able to evaluate the functionalities that fit the needs that its website wants to offer. The particular analysis of the design and structure of the site will determine the plugins to be used and the functionalities that they provide to customers.

Plugins are technological tools with great features available to help design websites, there is one for each project, budget, platform, and utility. 


\section{Phase X: Evolutionary phase}

Regardless of the type of site we are talking about (CRM, ERP or own web pages) it is important to maintain a communication channel with customers, since that implies, in many cases, keeping the potential customer.

With the integration of plugins, it is the fastest and most effective way possible to attend, answer questions, inform and disseminate promotions or advertising to customers. The inclusion of a direct or automatic chat is clearly one of the best and most used alternatives on business websites.

\section{Results}

Plugins are a powerful technological tool, save development time, easy to implement, inexpensive, compatible with various technologies and offer various functionalities safely and effectively. There is a great variety of them, of all kinds, and for the study of assertive communication on a business website, there are also plugins that solve the problem, by creating a communication channel with the client through the use of a chat.

The best way to maintain this channel is through a live chat, however at the same time an automatic chat could be opted for.

Every business website requires a connection with its customers where they maintain a direct interaction with them. To conclude, a communication channel is essential in a business website, a connection between the company and the client is necessary, and in some way the service link. It is also essential to mention that not only the chat allows assertive communication of customers, in the same way, the use of social networks such as Facebook and other messaging applications such as WhatsApp.

\section{Acknowledgment}

We thank Mtro. José Román Ruiz Carrillo, Rector of the Autonomous University of Campeche for the provision and support provided for the publication of this article. Similarly, recognition is extended to Mtro. Guadalupe Manuel Estrada Segovia, Director of the Faculty of Engineering for the empathy of promoting studies focused on research in the area of Computer Science.

\section{Conclusions}

The holistic process life cycle has been successfully applied to the problem raised, the analysis of the existence of an assertive communication channel through the use of plugins is feasible, reliable, economical and widely used today. The flexibility of plugin integration into business websites supports many communication capabilities with your customers. Allowing the company to apply marketing strategies to achieve the satisfaction and preference of its customers and thereby achieve better profits. Having an assertive communication channel is of great importance, to understand the needs of customers and significantly improve interaction with them. Having these technological tools significantly improves company-client communication, so it is highly recommended to implement them on business websites.

In the technological field, those interested in the design, construction and maintenance of websites, should also strengthen their domain in basic technological tools, such as plugins, given the benefits and strengths they provide with less investment in time and cost.

\section{References}

Aguiar, M. (2005). Un Nuevo Sujeto Para la Sociedad de la Información. Gesbiblo. SL.

Bernal, V. H. (2019). FASCINATION CX. desconocido: Victor Hugo Sanchez Bernal, 2019.

Carrasquero Medina, A. B. (2014). Investigación holística y Desarrollo Instruccional en la comprensión del discurso escrito en estudiantes de educación media de la U.E.N. José Félix Blanco. Caracas. Revista de Investigación, 38(81).

Hurtado de Barrera, J. (2006). El proyecto de investigacion: metodologia de la investigación holística. (2. Sypal, Ed.)

James Ariel Sánchez Alzate, L. A. (2016). Factores que afectan la confianza de los consumidores por las compras a través de medios electrónicos. Pensamiento \& Gestión, -. 
James Paul Linero Bocanegra, L. F. (2020). Hábitos de consumo en plataformas e-commerce en adultos jóvenes de la ciudad de Bogotá. Revista Universidad y Empresa, -.

Medina Rivilla, A., De La Herrán Gascón, A., \& Dominguez Garrido, M. C. (2014). Fronteras en la investigación de la Didáctica. Madrid: Universidad Nacional de Educación a Distancia.

Morlan, A. (28 de 02 de 2020). Todo Pa tu Web. Obtenido de https://www.todopatuweb.net/news/comotener-insertar-un-chat-en-tu-sitio-webfacilmente/

peciña, I. S. (2017). El Comercio Electrónico. Madrid: ESIC Editorial.

Tagle, J. (30 de 04 de 2020). WordPress Avanzado. Obtenido de https://wpavanzado.com/que-es-un-plugin/

Tony Million, A.-R. A. (2004). SECURE FLEXIBLE PLUGIN SOFTWARE ARCHITECTURE. 12.

WordPress.org. (s.f.). Plugin Handbook. Obtenido de https://developer.wordpress.org/plugins/wordpr ess-org/detailed-plugin-guidelines/\#the-plugindirectory

WordPress.org. (s.f.). WORDPRESS.ORG. Obtenido de https://codex.wordpress.org/Writing_a_Plugin

Borchert, S., \& Schirwinski, A. (2015). Drupal 8 Configuration Management. Packt Publishing Ltd.

Khan, R., \& Das, A. (2017). Build Better Chatbots: A Complete Guide to Getting Started with Chatbots. Apress.

Klein, L. (2015). WordPress Most Potent Plugins and Themes: 60 Reviews \& over 190 Themes \& Plugins Liste. Lambert Klein

Muldowney, O. (2017). Chatbots: An Introduction And Easy Guide To Making Your Own. Courses \& Magic

Reitsma, J. (2015). Programming Joomla Plugins. Lulu Press, Inc. 